\title{
Landscape Factors Influencing the Abundance and Dominance of the Invasive Plant Potentilla recta
}

\author{
Bryan A. Endress, ${ }^{1}$ Bridgett J. Naylor, ${ }^{2}$ Catherine G. Parks, ${ }^{3}$ and Steven R. Radosevich ${ }^{4}$ \\ Authors are ${ }^{1}$ Research Associate and ${ }^{4}$ Professor, Department of Forest Science, Oregon State University, Corvallis, OR 97331; and ${ }^{2}$ GIS Analyst and \\ ${ }^{3}$ Research Ecologist, USDA Forest Service, Pacific Northwest Research Station, La Grande, OR 97850.
}

\begin{abstract}
Little is known about the relative importance of environmental, biotic, historical, and spatial factors that influence invasive plant abundance, dominance, and distribution across landscapes. We identified factors that influence the abundance and dominance of Potentilla recta L. (sulfur cinquefoil) in bunchgrass grasslands of northeastern Oregon to better understand the conditions under which it becomes a major component of plant communities. We estimated P. recta stem density and dominance from field measurements across the landscape and used classification and regression tree analyses to assess the importance of environmental, biotic, spatial, and historical factors in explaining P. recta presence, stem density, and dominance. Plots were sampled within a systematic grid with 250 -m spacing within our $6.5-\mathrm{km}^{2}$ study landscape. At each sample point we recorded $P$. recta presence, stem density, and dominance as well as 11 biological, environmental, spatial, and historical variables. P. recta was widely distributed, with stem densities in occupied plots averaging 5.8 stems $\cdot \mathrm{m}^{-2}$ and dominance values ranging from $1 \%$ to $52 \%$. Percent cover of bare ground was the most important variable to predict the presence of $P$. recta, though the model fit was poor, likely because the entire study area is suitable for $P$. recta establishment. A strong relationship between $P$. recta dominance and habitat type $\left(r^{2}=67.5 \%\right)$ was found, with dominance greatest in old fields on relatively flat slopes (mean dominance of $34.1 \%$ ). Dominance estimates were $\leq 1 \%$ in plots located in forest, shrub, and grassland habitats. Factors that make old fields susceptible to dominance remain unknown, though microsite conditions that increase $P$. recta seedling survival rates and limited native propagule availability due to previous cultivation may be involved. Since old fields are found throughout the region, are highly susceptible to $P$. recta invasion, and represent a source of seeds, containment and restoration activities should focus on these areas.
\end{abstract}

\section{Resumen}

Poco se sabe acerca de la importancia relativa de los factores ambientales, bióticos, históricos y espaciales que influyen en la abundancia, dominancia y distribución a través del paisaje de las plantas invasoras. Identificamos factores que influyen en la abundancia y dominancia de Potentilla recta L. ("Sulfur cinquefoil") en los pastizales amacollados del nordeste de Oregon, para entender mejor las condiciones bajo las cuales llega a ser uno de los componentes principales de las comunidades vegetales. Estimamos la densidad de tallos y dominancia de $P$. recta a partir de mediciones de campo a través del paisaje y usamos análisis de árbol de Clasificación y Regresión para evaluar la importancia de los factores ambientales, bióticos, espaciales e históricos en explicar la presencia, densidad de tallos y dominancia del P. recta. Las parcelas fueron muestreadas dentro de una cuadrícula con una separación de 250-m entre puntos y dentro de nuestra área de estudio de $6.5 \mathrm{~km}^{2}$. En cada punto de muestro registramos la presencia, densidad de tallos y dominancia de $P$. recta, así como otras 11 variables biológicas, ambientales, espaciales e históricas. El P. recta estuvo ampliamente distribuido, con un promedio de densidad de tallos de 5.8 tallos $\mathrm{m}^{-2} \mathrm{y}$ los valores de dominancia variaron de $1 \%$ to $52 \%$. El porcentaje de suelo desnudo fue la variable más importante para predecir la presencia de $P$. recta, aunque el ajuste del modelo fue pobre, probablemente porque toda el área de estudio es apropiada para el establecimiento de $P$. recta. Se encontró una estrecha relación entre la dominancia de $P$. recta y el tipo de hábitat $\left(r^{2}=67.5\right)$, con la mayor dominancia en los campos viejos en pendientes relativamente planas (dominancia promedio de 34.1\%). Las estimaciones de dominancia en las parcelas localizadas en hábitat de bosque, matorral y zacatal fueron $\leq 1 \%$. Los factores que hacen a los campos viejos susceptibles para ser dominados por esta especie son aun desconocidos, aunque las condiciones de micrositio que incrementan la tasa de supervivencia de las plántulas de $P$. recta y la limitada disponibilidad de propágulos de especies nativas debido a las prácticas previas de cultivo del campo, pueden estar involucrados. Dado que los campos viejos se encuentran a en toda la región son altamente susceptibles a la invasión de $P$. recta y representan una fuente de semilla, por lo que las actividades de contención y restauración deben enfocarse en estas áreas.

Key Words: invasive plants, noxious weeds, Oregon, Blue Mountains, landscape ecology, bunchgrass rangelands

Research was funded by the USDA Forest Service, Pacific Northwest Research Station, and the Center for Invasive Plant Management.

Correspondence: Bryan A. Endress, Forestry and Range Sciences Laboratory, 1401 Gekeler La, La Grande, OR 97850. Email: bryan.endress@oregonstate.edu

Manuscript received 26 February 2006; manuscript accepted 2 March 2007.

\section{INTRODUCTION}

In the past several decades, the impact of exotic, invasive plants on ecological patterns and processes has been recognized, and invasive species are considered a significant threat to biodiversity and the composition, structure, and function of local 
and regional ecosystems (D'Antonio and Vitousek 1992; Vitousek et al. 1996; Mack et al. 2000). Invasive, exotic species pose a significant economic and ecological problem to western forests and rangelands, and it has been estimated that exotic species in western rangelands cost $\$ 1$ billion per year in forage losses and $\$ 5$ billion per year to control (Pimentel et al. 2000). As a result, the causes and consequences of exotic plant invasions in rangelands have received considerable attention from scientists, and invasive plant management is now a central component of many land managers' activities.

In some ecosystems, exotic species reach such high abundances (density, biomass, cover) that they become community dominants. These situations pose the greatest threat to native ecosystems because dominant species set the environmental context for the persistence and abundance of other species (Huston 1994; Keddy 2001; Denslow and Hughes 2004). Despite the attention exotic plant invasions have received in recent years, little is known about the relative importance of environmental, biotic, historical, and spatial factors that influence landscape-level patterns of exotic plant abundance, dominance, and distribution (Parks et al. 2005). This lack of understanding of the invasion process hinders the development of efficient, cost-effective approaches to invasive plant management. Environmental and biological information also can be useful in the development of predictive models of invasive plant spread to better inform invasive plant management programs. Anticipating the establishment and spread of invasive plant species is important, as invasions are often easiest to control early in the invasion process. Moreover, invasive plant management is expensive and time consuming, and information to prioritize management actions is highly desirable (Andersen et al. 2004; Endress et al. 2006). Unfortunately, few studies have taken an integrated approach to predict and contain invasive plant species in the forests and rangelands of the interior Pacific Northwest (but see Shafii et al. 2003, 2004; Radosevich et al. 2005).

Estimates of invasive plant success in particular habitats are usually based on presence/absence, absolute cover, or biomass data. Recently, it has been suggested that dominance, or the relative cover or biomass of a species, may be a better measurement to estimate and characterize plant invasions and their potential impact on plant communities (Lundholm and Larson 2004). Measurements of absolute cover or biomass often underestimate the degree to which an invasive plant species is abundant relative to native species, particularly when total foliar cover is considerably lower than $100 \%$, as is the case in arid and semiarid ecosystems (Lundholm and Larson 2004). In addition, many invasive plant species found in the interior Pacific Northwest have broad ecological amplitude and are able to establish, even at very low abundances, in a wide range of habitats (Parks et al. 2005). For species with broad ecological amplitude, the conditions whereby it can dominate a plant community should be identified. Knowing the likelihood of dominance is useful because it assists in the prioritization of management actions, including inventory, monitoring, eradication, control, and restoration activities.

Potentilla recta is a relatively recent introduction to the interior Pacific Northwest, and many new infestations have reached environmentally severe sizes and densities (Rice 1999). It is native to Eurasia and was introduced into North America prior to 1900 . The species has since spread across the continent. The plant reproduces only by seed. In northeastern Oregon, $P$. recta can live to 10 years of age (Perkins et al. 2006). Adult plants are prolific seed producers with up to 6000 seeds produced per plant per year (Dwire et al. 2006). In eastern North America, it is a minor agricultural weed, but in the drier climates of the West, $P$. recta forms dense populations in several native plant communities (Rice 1999). Zouher (2003) found that $P$. recta established and persisted in 53 and 32 different land cover types identified by the Society for Range Management and the Society for American Foresters, respectively. These land cover types range from bluebunch wheatgrass grasslands to white spruce-aspen forests. While numerous plant communities are at risk to invasion by $P$. recta, little is known about the relative risk of different plant communities.

In this study, we identify factors that influence landscapelevel patterns of abundance and dominance of $P$. recta $\mathrm{L}$ (sulfur cinquefoil) in the low-elevation rangelands of northeastern Oregon to better understand the conditions under which it becomes a major component of plant communities. Specifically, our objectives were to: 1 ) estimate stem density and dominance of $P$. recta; and 2) assess the importance of environmental, biotic, spatial, and historical factors in explaining presence, stem density, and dominance of the species.

\section{MATERIALS AND METHODS}

\section{Study Site}

Our research is focused on the low-elevation $(<2000 \mathrm{~m})$ rangelands of the Blue Mountains ecoregion of northeastern Oregon and southeastern Washington. Perennial bunchgrass communities dominate the area, but the region also contains forest stands of ponderosa pine (Pinus ponderosa P. \& C. Lawson) and Douglas-fir (Pseudotsuga menziesii [Mirbel] Franco var. menziesii). Bunchgrass communities in the region have undergone considerable change in the past 150 years. These grasslands are typically dominated by perennial bunchgrass species including Psendoroegneria spicata (Pursh) A. Löve, Poa secunda J. Presl, and Festuca idahoensis Elmer. Cultivation, grazing, altered fire regimes, and the introduction of exotic plant species have resulted in their transition to grasslands dominated by exotic grass and forb species (Johnson and Swanson 2005; Parks et al. 2005). Bunchgrass rangelands are considered one of the most altered ecosystems in the interior Pacific Northwest (Bunting et al. 2002) and contain the greatest number of exotic species of all ecosystems in Oregon (Parks et al. 2005). Many bunchgrass communities are now dominated by a mix of exotic species including several annual grasses (Bromus tectorum L., Taeniatherum caput-medusae L. [Nevski], Ventenata dubia [Leers] Coss. \& Durieu) and a number forbs (Centaurea spp., Linaria spp., P. recta) (Parks et al. 2005).

Our research was conducted in Wenaha State Wildlife Area near Troy, Oregon. Elevation ranges from 900 to $1150 \mathrm{~m}$, and annual precipitation averages $430 \mathrm{~mm} \cdot \mathrm{y}^{-1}$ (Western Regional Climate Center, Reno, NV). Most precipitation occurs from October through May with the warm, drier summer months characterized by periodic thunderstorms. The area is representative of the low-elevation rangelands of the Blue Mountain 
ecoregion in terms of habitats and land use history. The area is characterized by a matrix of open coniferous forest $(P$. ponderosa, P. menziesii var. menziesii), abandoned agricultural fields (dominated by Poa bulbosa L., Bromus inermis Leyss., and Poa pretensis L.), and perennial bunchgrass (P. spicata, P. secunda, F. idahoensis) plant communities. As with many areas of the region, intense land use began with the expansion of cattle and sheep ranching and the conversion of bunchgrass rangeland to agricultural fields and as part of the US Homestead Act of 1865 (Jordan 1954; Galbraith and Anderson 1971; Carrey et al. 1979). The rugged landscape, arid environment, and the difficulty in meeting livelihood needs resulted in abandonment of most agricultural fields (Jordan 1954; Carrey et al. 1979). Currently, the predominant land use activities are cattle grazing and big game hunting (elk [Cervus elaphus] and mule deer [Odocoileus hemiones]).

\section{Sampling Design}

A systematic grid was established with $250-\mathrm{m}$ spacing within a $6.5-\mathrm{km}^{2}$ area along Eden Bench, part of the Wenaha State Wildlife Area, using Geographic Information Systems (GIS) technologies (ESRI ArcGIS 8.3). During July 2003, each sample point in the grid was found using real-time differential global positioning systems (Trimble Pathfinder ProXRS; Trimble 2002), and at each sample point, we delineated a 22.7-mdiameter circular plot $\left(405 \mathrm{~m}^{2}\right)$. This plot size was chosen for use in a companion photodetection study for $P$. recta (Naylor et al. 2005). The presence of $P$. recta, slope, aspect, and tree canopy cover (visual estimate using the following percent cover categories: $0,1,1-5,5-25,25-50,50-75,75-95,95-99,100)$ were estimated for each plot $(n=80)$. Plots were also classified into 1 of 5 habitat categories, which included grassland (grass dominated areas with $<5 \%$ tree canopy cover and $<25 \%$ shrub cover), shrubland ( $<5 \%$ tree canopy cover and $>25 \%$ shrub cover), open forest $(5 \%-50 \%$ tree canopy cover), forest ( $\geq 50 \%$ tree canopy cover), and abandoned agricultural fields ("old fields").

Within each $405-\mathrm{m}^{2}$ plot, twelve $1-\mathrm{m}^{2}$ quadrats were established for intensive sampling. The $1-\mathrm{m}^{2}$ plots were spatially arranged throughout the plot in the following pattern: plots were established $3 \mathrm{~m}$ and $9 \mathrm{~m}$ from the plot center in each the cardinal directions $(\mathrm{N}, \mathrm{S}, \mathrm{E}, \mathrm{W})$ and $6 \mathrm{~m}$ from the plot center in NE, SE, NW, and SW directions. At each quadrat, percent canopy cover was recorded for $P$. recta, total vegetation $(<1 \mathrm{~m}$ in height), and vegetation by general life form categories (i.e., forbs, graminoids, shrubs). Percent cover for bare ground and rock cover were also recorded. Cover was visually estimated using the following percent cover classes: 0 , $<1,1-5,5-15,15-25,25-35,35-45,45-55,55-65,65-75$, $75-85,85-95,>95$. If $P$. recta was present, the total number of stems in each quadrat was recorded. Dominance (relative cover) was calculated by dividing the percent cover of $P$. recta of a quadrat by the total vegetation cover of that quadrat.

\section{Geographic Information Systems}

In addition to collecting data in the field, several landscape variables were also calculated using GIS software (ESRI ArcGIS 8.3). These calculations included distance $(\mathrm{m})$ to the nearest water source (stream, pond, spring, and so on), distance (m) to the nearest road, elevation, and soil type. Water sources and roads were digitized from 1:6 000 scale georectified natural color aerial photographs (Naylor et al. 2005) and grayscale digital orthographic quadrangles (USDA Forest Service 2001). Distance measurements to the nearest water source or road feature were calculated using ArcGIS 8.3. These variables were of interest because the abundance of several exotic rangeland weeds is positively related to either roads or riparian areas (Parks et al. 2005). Soil data were from the NRCS Soil Survey Geographic (SSURGO) database for Wallowa County Area, Oregon (USDA, NRCS 2005) and were classified to the soil great group taxonomic level, which differentiates soils based on the development of pedogenic horizons, soil moisture, and base status. In this study, 4 soil great groups were identified: haploxerolls, argixerolls, haploxeralfs, and soils comprised of both argixerolls and haploxerolls.

\section{Analysis}

Classification and regression tree analyses (CART) were conducted to identify the most important variables explaining $P$. recta presence, stem density, and dominance. CART models are ideally suited to identify ecological patterns and processes, including factors that influence the abundance and distribution of species (De'ath and Fabricius 2000; Wiles and Brodahl 2004; Taverna et al. 2005). CART models are nonparametric models that explain variation of a single response variable (e.g., $P$. recta density) by recursive partitioning of the data set into more homogeneous data subsets, using combinations of explanatory variables (Urban 2002). Explanatory variables may be categorical and/or continuous. CART estimates model fit by calculating $r^{2}$; when the response variable is categorical (e.g., $P$. recta presence), model quality is estimated by its misclassification rate. CART analysis represents a relatively new and powerful alternative to traditional statistical techniques, including analysis of variance and linear, multiple, and logistic regression analyses, where it is difficult to analyze nonlinear relationships, high-order interactions, missing values, or data that are highly skewed or multimodal (De'ath and Fabricius 2000; Urban 2002; Taverna et al. 2005).

Three CART analyses (CART version 5.0; Salford Systems 2002) were performed using 79 of the $80,405-\mathrm{m}^{2}$ circular plots for 3 different independent variables: $P$. recta presence, stem density, and dominance. One plot was dropped from the analyses because of a GPS malfunction that resulted in loss of the data. Each of the 79 remaining plots was classified for presence or absence of $P$. recta based on field sampling. Plot estimates of $P$. recta dominance and stem density were determined by calculating the mean values of those 2 variables from the $12,1-\mathrm{m}^{2}$ plots. For 18 of the 79 plots, P. recta was found but was not abundant enough to occur in any of the 12 , $1-\mathrm{m}^{2}$ sampling quadrats. In these cases, we assigned a dominance value of $0.1 \%$ and stem density value of 0.01 stems $\cdot \mathrm{m}^{-2}$. A strong positive correlation between dominance and stem density $(r=0.85, P<0.0001)$ was found, and for that reason the CART analysis for stem density is not presented.

Explanatory variables entered into the models are found in Table 1. The CART trees were constructed automatically using the Gini Method with a minimum parent node of 10 
Table 1. Variables used in classification and regression tree analyses to identify factors influencing Potentilla recta presence and dominance near Troy, Oregon.

\begin{tabular}{|c|c|c|}
\hline Variable & Type & Source \\
\hline \multicolumn{3}{|l|}{ Response variables } \\
\hline$P$. recta presence & Categorical & Field measurement in $405-\mathrm{m}^{2}$ plots \\
\hline P. recta dominance & Numeric & Mean field measurement of $12,1-\mathrm{m}^{2}$ plots \\
\hline \multicolumn{3}{|l|}{ Explanatory variables } \\
\hline Soil type & Categorical & Soil Survey database (USDA, NRCS 2005) \\
\hline Aspect & Categorical & Field measurement in $405-\mathrm{m}^{2}$ plots \\
\hline Slope & Numeric & Field measurement in $405-\mathrm{m}^{2}$ plots \\
\hline Elevation & Numeric & 10-m Digital Elevation Model (USDA 2000) \\
\hline Habitat & Categorical & Field measurement in $405-\mathrm{m}^{2}$ plots \\
\hline Tree canopy cover & Numeric & Field measurement in $405-\mathrm{m}^{2}$ plots \\
\hline Shrub cover & Numeric & Mean field measurement of $12,1-\mathrm{m}^{2}$ plots \\
\hline Rock cover & Numeric & Mean field measurement of $12,1-\mathrm{m}^{2}$ plots \\
\hline Bare ground cover & Numeric & Mean field measurement of $12,1-\mathrm{m}^{2}$ plots \\
\hline Distance to water & Numeric & Spatial Join in ESRI ArcGIS 8.3 \\
\hline Distance to road & Numeric & Spatial Join in ESRI ArcGIS 8.3 \\
\hline
\end{tabular}

observations (Salford Systems 2002). The success of the CART analyses were assessed by 10 -fold cross validation using the 1SE rule (De'Ath and Fabricius 2000; Salford Systems 2002). Cross validation was conducted to select the classification tree sizes and estimate error rates for trees of a given size. When the response variable is a continuous, numeric variable (e.g., $P$. recta dominance), CART estimates the model fit by calculating $r^{2}$; when the response variable is categorical (e.g., P. recta presence), the quality of the model is estimated by its misclassification rate. The misclassification rate is the proportion of observations that have been misclassified (e.g., a plot where the model suggests $P$. recta should be absent but the species is actually present).

\section{RESULTS}

P. recta was found in 59 of the 79 sampled plots $(74.7 \%)$, although canopy cover, stem density, and dominance varied considerably among plots. Mean percent cover of $P$. recta in occupied plots was $3.5 \%(\mathrm{SD}=7.6$; median $=2.0)$ with a maximum value of $34 \%$. Stem density in occupied plots averaged 5.8 stems $\cdot \mathrm{m}^{-2} \quad(\mathrm{SD}=9.9$; median $=2.6)$ with a maximum value of $87 \mathrm{stems} \cdot \mathrm{m}^{-2}$. P. recta dominance ranged from $1 \%$ to $52 \%$ with a mean dominance of $6.5 \%$ $(\mathrm{SD}=13.0 ;$ median $=5.2 \%)$.

The classification tree indicated that bare ground was the most important variable predicting the presence of $P$. recta (Fig. 1). Plots with $\geq 18 \%$ cover of bare ground were more likely to have $P$. recta $(89 \%)$ than plots with $<18 \%$ bare ground $(53 \%)$. Nearly $98 \%$ of the plots with bare ground ranging from $18 \%$ to $48 \%$ contained $P$. recta. Cross validation revealed that only $61 \%$ of observed plots were correctly classified, and the model explained $34.3 \%$ of the variance. Other explanatory variables in this analysis (e.g., shrub cover, soil type, aspect, and so on; Table 1) did not

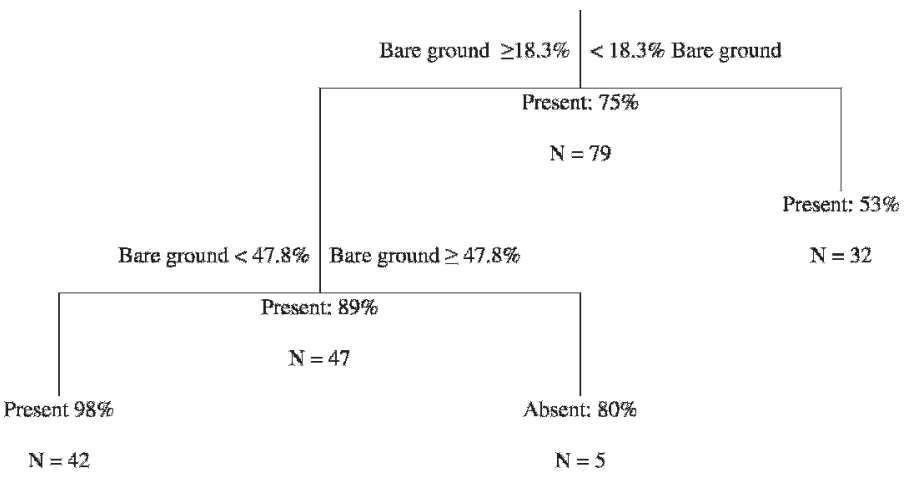

Figure 1. Classification tree for the presence/absence of Potentilla recta in the Wenaha State Wildlife Management Area near Troy, Oregon. Each split is labeled (classified) according to whether $P$. recta is predominantly present or absent, the percentage of observations in that class, the number of observations, and the proportion of variance explained by the split. The misclassification rate for $P$. recta presence is based on 10 -fold cross validation of the data was $39 \%$.

explain a sufficient amount of variation to be retained in the final CART tree.

The CART model developed to identify factors for $P$. recta dominance differed from the presence/absence model and indicated that habitat type was most important predictor of P. recta dominance (Fig. 2). Dominance was greatest in old fields (mean dominance of $18.7 \%$ ), while it was much lower for plots located in forest $(0.2 \%)$, open forest $(0.5 \%)$, shrub $(0.8 \%)$, and grassland (1.0\%) habitats (Fig. 3). A 1-way analysis of variance (ANOVA; Welch's ANOVA for samples with unequal variances using PROC GLM; SAS Institute Inc. 2000) found that these differences were significant ( $\mathrm{df}=4,75$,

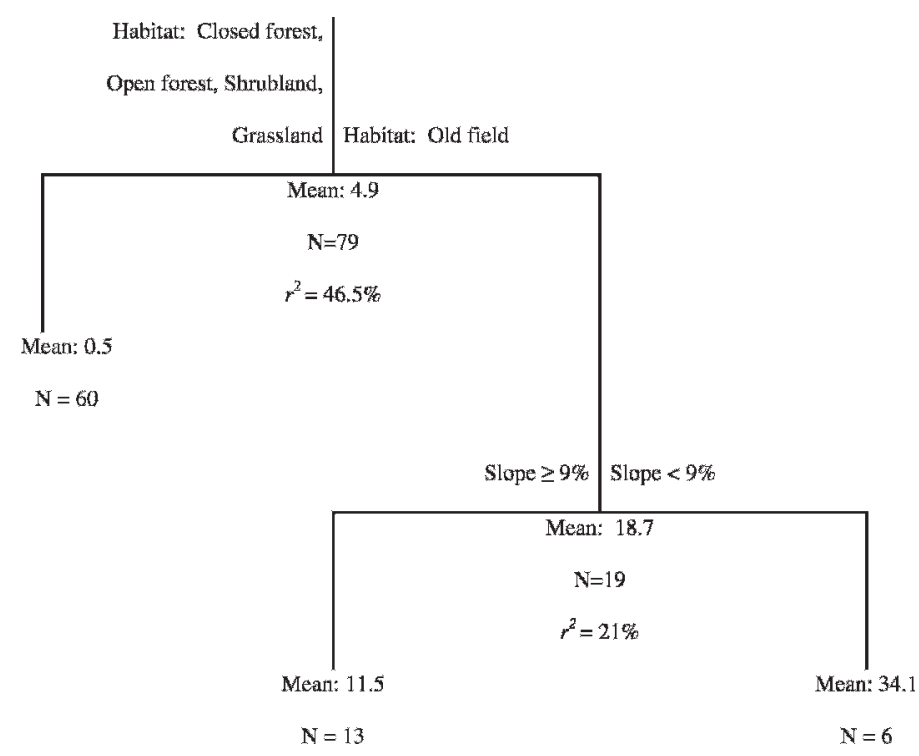

Figure 2. Regression tree analysis for dominance of Potentilla recta in the Wenaha State Wildlife Management Area near Troy, Oregon. The 2 splits (nonterminal nodes) are labeled with the explanatory variable (e.g., slope, habitat), the values that determined the splits, as well as the mean dominance (mean \%), number of observations $(N)$, and proportion of variance explained by the split $\left(r^{2}\right)$. Each node is labeled with the mean $P$. recta dominance $(\%)$ and the number of observations in each group. The tree explained $\left(r^{2}\right) 67.5 \%$ of the total variance. 


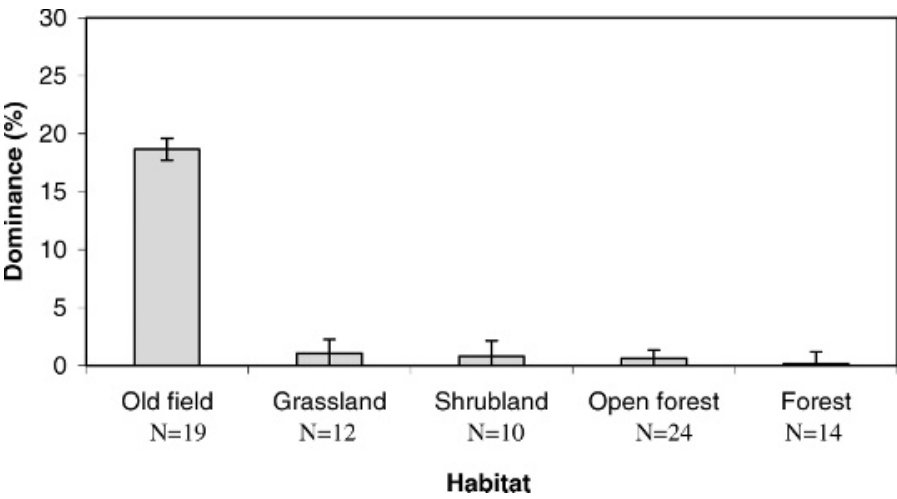

Figure 3. Mean dominance ( $\pm 1 \mathrm{SE})$ of Potentilla recta among different habitat types in the Wenaha State Wildlife Management Area near Troy, Oregon. Dominance values were significantly different among habitat types $(P=0.0013)$.

$F=6.12, P=0.0013)$. This analysis further split old fields into 2 groups based on slope. Old fields on low slopes $(<9 \%)$ had the greatest $P$. recta dominance values, averaging $34.1 \%$, as compared to dominance value of $11.5 \%$ for old fields with slopes $>9 \%$. Regardless of habitat type, dominance decreased as slope increased (Fig. $4 ; r^{2}=0.166, P=0.0003$ ). Cross validation of the CART tree revealed that the model explained $67.5 \%$ of the data variance. Because of the strong correlation between dominance and stem density, old fields also had the highest mean density of $P$. recta $\left(19.2\right.$ stems $\left.\cdot \mathrm{m}^{-2}\right)$, compared to other habitats, where mean stem densities were less than 1 stem $\cdot \mathrm{m}^{-2}$. These differences were also significant (Welch's 1-way ANOVA; $\mathrm{df}=4,75 F=4.18, P=0.011$ ).

\section{DISCUSSION}

P. recta is widely distributed throughout our study landscape, and dominance is most strongly related to past land use. Mean dominance of $P$. recta in old fields is more than 37 times greater than in other habitats. The CART model for explaining $P$. recta presence was poor, with a high rate of misclassification. The poor fit of this model is likely due to the fact that all the habitats along Eden Bench are generally suitable to P. recta establishment.

Results from this study suggest that dominance by $P$. recta may be less attributable to competition than has been previously supposed; rather, $P$. recta dominance is the product of the synergism between $P$. recta invasion, disturbance, and land use/land cover change. Thus, rather than driving the transformation of native bunchgrass communities, $P$. recta may be a "passenger" of more fundamental environmental changes that limit native flora, such as reduced dispersal of native species due to cultivation and habitat fragmentation. Similar patterns have been found in other ecosystems (e.g., Seabloom et al. 2003; Corbin and D'Antonio 2004; Didham et al. 2005; MacDougall and Turkington 2005). For example, past land use was the strongest predictor of the abundance and distribution of 3 invasive species in secondary forests in the eastern United States (Lundgren et al. 2004). Similarly, the density of 3 invasive plants in Spain was greatest in abandoned fields or in woodlands that were former agricultural areas (Vilà et al.

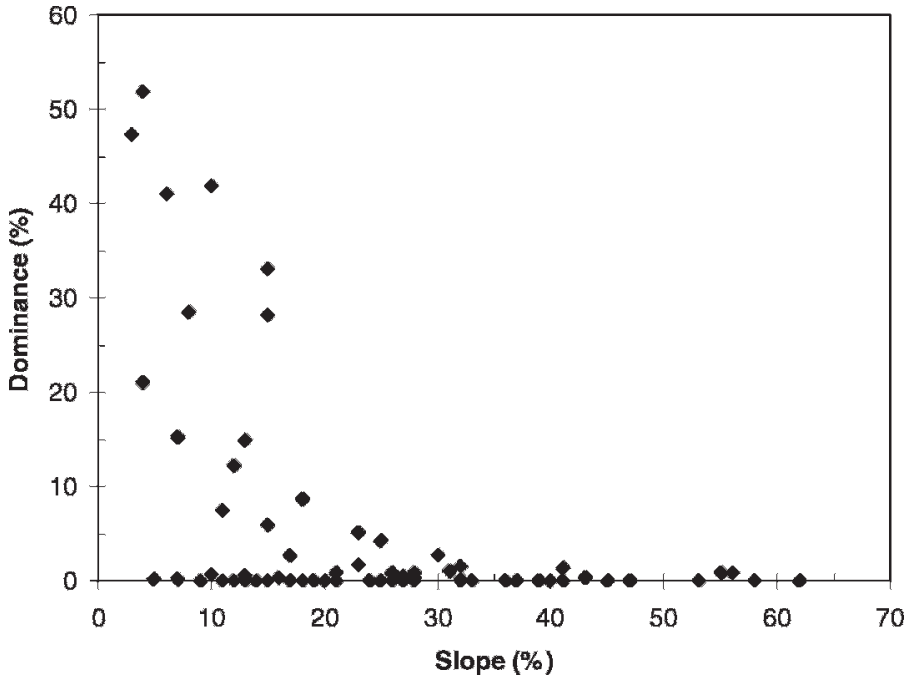

Figure 4. Dominance of Potentilla recta (relative $P$. recta cover) vs. slope from 79 plots sampled in the Wenaha Wildlife Management Area in northeastern Oregon. Dominance was calculated as the percent cover of $P$. recta/percent total vegetation cover.

2003; Domènech et al. 2005). The relationship between land use history and exotic plant dominance should not be particularly surprising since past land use has been shown to affect a wide range of ecological patterns and processes and in many cases has a greater influence on plant abundance and plant community structure and composition than biophysical factors (Motzkin et al. 1996; Foster et al. 1998; de Blois et al. 2001). However, this relationship has not received much attention in western North America rangelands despite the considerable amount of area cultivated, even briefly, as part of the western migration of settlers. Abandoned agricultural fields dominate most of the flat bench areas in the low-elevation landscape of the Blue Mountain ecoregion, and these areas contain the greatest number of listed exotic weed species for all plant communities in the state of Oregon (Parks et al. 2005). Future research should focus on the mechanisms that influence invasive plant dominance and rangeland community dynamics in areas exposed to intense land use and under what conditions particular land use activities have the greatest impact on exotic plant establishment and dominance. Such studies could provide valuable insight into landscape patterns of invasive plant spread, abundance, and dominance.

While this study showed clear differences in dominance among habitats, the underlying factors that make previously cultivated areas susceptible to dominance remain unclear. In some cases, $P$. recta can establish readily the first year following cultivation (Perkins et al. 2006), and seedling densities can be high in abandoned fields (Tuitele-Lewis 2004). Generally, seedling mortality of P. recta is often $>95 \%$ (Tuitele-Lewis 2004). However, microsite factors, such as increased soil moisture, may increase $P$. recta seedling establishment in abandoned fields. Relatively flat areas, such as the abandoned fields in this study, generally have deeper soils with higher moisture content than sloped areas. If soils in old fields maintain higher soil moisture levels later in the summer in the top several centimeters of soil than areas not previously cultivated, seedling survival rates could increase, 
resulting in increased establishment and subsequent $P$. recta dominance. Soil moisture differences may also explain the negative relationship between slope and $P$. recta dominance. Another factor that may allow $P$. recta to dominate previously cultivated sites is a limited seed bank that reduces establishment and competition from other species. Limited native propagule availability has been hypothesized as a factor influencing exotic plant abundance and dominance at the community level in other grassland and savannah systems (e.g., Seabloom et al. 2003; MacDougall and Turkington 2005; Hobbs et al. 2006), though it has been rarely evaluated.

While $P$. recta densities were low in grassland and forest habitats, it is unclear if future densities will remain low or increase to those found in the old fields. It is unlikely that low densities in forest and grasslands are due to low propagule supply because P. recta is a prolific seed producer (Dwire et al. 2006), is widely distributed throughout the area (e.g., found in $75 \%$ of our plots), and is extremely dense in many areas with a maximum stem density recorded at $157 \mathrm{stems} \cdot \mathrm{m}^{-2}$ (Naylor et al. 2005). However, our results suggest that these habitats are more resistant to invasion than old fields. The underlying reasons for this resistance are unknown, though these may also be microhabitat related (e.g., increased shade in forest and low soil moisture along bunchgrass communities found on slopes).

\section{MANAGEMENT IMPLICATIONS}

Since old fields are found throughout the low-elevation rangelands of the Blue Mountain ecoregion, are highly susceptible to $P$. recta invasion, and represent fixed locations that produce a considerable source of seed for further invasion into less disturbed areas, containment and restoration activities should focus on these areas. Restoration is important because recolonization by native species appears limited, and herbicide and prescribed fire applications alone do not prevent recolonization by $P$. recta (Lesica and Martin 2003). Thus, many common weed control techniques (e.g., herbicide application, tillage, mowing) are likely to offer only shortterm reductions in invasive plant abundance. Low abundances of $P$. recta were found in other habitats, but it is uncertain if these populations will expand in the future. In northeastern Oregon, many perennial bunchgrass grasslands and ponderosa pine stands contain $P$. recta, but not at dominance or stem densities levels found in old fields. Monitoring and managing populations in these areas would be a useful strategy to prevent and contain $P$. recta expansion in the intermountain West.

\section{ACKNOWLEDGMENTS}

Research was funded by the Center for Invasive Plant Management and a Joint-Venture Agreement between Oregon State University and the Pacific Northwest Research Station. Authors thank Rick Madigan and the Oregon Department of Fish and Wildlife for their support. Anne Bartuszevige, Manuela Huso, and 2 anonymous reviewers provided helpful for comments and suggestions on previous versions of this manuscript.

\section{LITERATURE CITED}

Andersen, M. C., H. Adams, B. Hope, and M. Powell. 2004. Risk analysis for invasive species: general framework and research needs. Risk Analysis 24: 893-900.

Bunting, S. C., J. K. Kingery, M. A. Hemstrom, M. A. Schrieder, R. A. Gravenmier, and W. J. Hann. 2002. Altered rangeland ecosystems in the interior Columbia Basin. Portland, OR: Pacific Northwest Research Station, USDA Forest Service. PNWGTR-553. $71 \mathrm{p}$.

Carrey, J., C. Conley, and A. Barton. 1979. Snake River in Hells Canyon. Cambridge, ID: Backeddy Books. 399 p.

CoRbin, J. D., AND C. M. D'Antonio. 2004. Competition between native perennial and exotic annual grasses: implications for an historical invasion. Ecology $85: 1273-1283$.

D’Antonio, C. M., And P. M. Vitousek. 1992. Biological invasions by exotic grasses, the grass-fire cycle, and global change. Annual Review of Ecology and Systematics 23:63-87.

DE'Ath, G., AND K. A. Fabricius. 2000. Classification and regression trees: a powerful yet simple technique for ecological data analysis. Ecology 81:3178-3192.

dE Blols, S., G. Domon, and A. Bouchard. 2001. Environmental, historical, and contextual determinants of vegetation cover: a landscape perspective. Landscape Ecology 16:421-436.

Denslow, J. S., and R. F. Hughes. 2004. Exotic plants as ecosystem dominants. Weed Technology 18:1283-1287.

Didham, R. K., J. M. Tylianakis, M. A. Hutchison, R. M. Ewers, and N. J. Gemmell. 2005. Are invasive species the drivers of ecological change? Trends in Ecology \& Evolution 20:470-474.

Domènech, R., M. Vila, J. Pino, and J. Gesti. 2005. Historical land-use legacy and Cortaderia selloana invasion in the Mediterranean region. Global Change Biology 11:1054-1064.

Dwire, K. A., C. G. Parks, M. L. Mclnnis, and B. J. Naylor. 2006. Seed production and dispersal of sulfur cinquefoil, an invasive non-native species in northeast Oregon. Rangeland Ecology and Management 59:63-72.

Endress, B. A., S. R. Radosevich, B. J. Naylor, J. Wells, and C. G. Parks. 2006. Beyond inventory/survey and monitoring: risk assessment and management. In: L. J. Rew and M. L. Pokorny [EDs.]. Inventory and survey methods for nonindigenous plant species. Bozeman: Montana State University Extension. p 70-74.

Foster, D. R., G. Motzkin, and B. Slater. 1998. Land-use history as long-term broad-scale disturbance: regional forest dynamics in central New England. Ecosystems 1:96-119.

Galbraith, W. A., and E. W. Anderson. 1971. Grazing history of the Northwest. Journal of Range Management 24:6-12.

Hobbs, R. J., S. Arico, J. Aronson, J. S. Baron, P. Bridgewater, V. A. Cramer, P. R. Epstein, J. J. Ewel, C. A. Klink, A. E. Lugo, D. Norton, D. Ojima, D. M. Richardson, E. W. Sanderson, F. Valladares, M. Vila, R. Zamora, and M. Zobel. 2006. Novel ecosystems: theoretical and management aspects of the new ecological world order. Global Ecology and Biogeography 15: $1-7$.

Huston, M. A. 1994. Biological diversity: The coexistence of species on changing landscapes. New York, NY: Cambridge University Press. $601 \mathrm{p}$.

JoHnson, C. G., AND D. K. Swanson. 2005. Bunchgrass plant communities of the Blue and Ochoco Mountains: A guide for managers. Portland, OR: USDA Forest Service, PNW-GTR-641. 119 p.

JoRdan, G. 1954. Home below Hell's Canyon. Lincoln: University of Nebraska Press. 243 p.

Keddy, P. A. 2001. Competition. Boston, MA: Kluwer Academic Press. 552 p.

Lesica, P., and B. Martin. 2003. Effects of prescribed fire and season of burn on recruitment of the invasive exotic plant, Potentilla recta, in a semiarid grassland. Restoration Ecology 11:516-523.

Lundgren, M. R., C. J. Small, and G. D. Dreyer. 2004. Influence of land use and site characteristics on invasive plant abundance in the Quinebaugh Highlands of southern New England. Northeastern Naturalist 11:313-332.

LundHolm, J. T., AND D. W. LARSON. 2004. Dominance as an overlooked measure of invader success. Biological Invasions 6:505-510. 
MacDougall, A. S., and R. Turkington. 2005. Are invasive species the drivers or passengers of change in degraded ecosystems? Ecology 86:42-55.

Mack, R. N., D. Simberloff, W. M. Lonsdale, H. Evans, M. Clout, and F. A. Bazzaz. 2000. Biotic invasions: causes, epidemiology, global consequences, and control. Ecological Applications 10:698-710.

Motzkin, G., D. Foster, A. Allen, J. Harrod, and R. Boone. 1996. Controlling site to evaluate history: vegetation patterns of a New England sand plain. Ecological Monographs 66:345-365.

Naylor, B. J., B. A. Endress, And C. G. Parks. 2005. Multi-scale detection of sulfur cinquefoil using aerial photography. Rangeland Ecology \& Management 58:447-551.

Parks, C. G., S. R. Radosevich, B. A. Endress, B. J. Naylor, D. Anzinger, L. J. Rew, B. D. Maxwell, and K. A. Dwire. 2005. Natural and land-use history of the Northwest mountain ecoregions (USA) in relation to patterns of plant invasions. Perspectives in Plant Ecology Evolution and Systematics 7: 137-158.

Perkins, D. L., C. G. Parks, K. A. Dwire, B. A. Endress, and K. Johnson. 2006. Age determination of sulfur cinquefoil (Potentilla recta L.) in Northeast Oregon using growth rings. Weed Science 54:87-93.

Pimentel, D., L. Lach, R. Zuniga, and D. Morrison. 2000. Environmental and economic costs of nonindigenous species in the Unites States. Bioscience 50:53-65.

Radosevich, S. R., B. A. Endress, and C. G. Parks. 2005. Defining an approach for regional invasive species research and management. In: K. Inderjet [ED.]. Ecological and agricultural aspects of invasive plants. Basel, The Netherlands: Birkhauser-Verlag Publishers. p 141-166.

Rice, P. M. 1999. Sulfur cinquefoil. In: R. L. Sheley and J. K. Petroff [eds.], Biology and management of noxious rangeland weeds. Corvallis, OR: Oregon State University Press. p 382-387.

Salford Systems. 2002. CART for Windows version 5.0. San Diego, CA: Salford Systems.

SAS InStITUTE Inc. 2000. Statistics II: ANOVA and regression course notes. Cary, NC: SAS Institute Inc. $494 \mathrm{p}$.

Seabloom, E. W., E. T. Borer, V. L. Boucher, R. S. Burton, K. L. Cottingham, L. Goldwasser, W. K. Gram, B. E. Kendall, and F. Micheli. 2003. Competition, seed limitation, disturbance, and reestablishment of California native annual forbs. Ecological Applications 13:575-592.
Shafi, B., W. J. Price, T. S. Prather, L. W. Lass, and D. C. Thill. 2003. Predicting the likelihood of yellow starthistle (Centaurea solstitialis) occurrence using landscape characteristics. Weed Science 51:748-751.

Shafil, B., W. J. Price, T. S. Prather, L. W. Lass, and D. C. Thill. 2004. Using landscape characteristics as prior information for Bayesian classification of yellow starthistle. Weed Science 52:948-953.

Taverna, K., D. L. Urban, and R. I. McDonald. 2005. Modeling landscape vegetation pattern in response to historic land-use: a hypothesis-driven approach for the North Carolina Piedmont, USA. Landscape Ecology 20:689-702.

Trimble Navigation Limited. 2002. GPS Pathfinder for Office: Getting started guide. Version 2.90. Sunnyvale, CA: Trimble Navigation Limited Mapping and GIS Division. $76 \mathrm{p}$

Tuitele-Lewis, J. 2004. The biology and ecology of Potentilla recta in the Blue Mountains of northeastern Oregon [thesis]. Corvallis, OR: Oregon State University. $123 p$

Urban, D., S. Goslee, K. Pierce, and T. Lookingbill. 2002. Extending community ecology to landscapes. Ecoscience 9:200-212.

USDA Forest Service. 2000. 10 Meter Digital Elevation Model Grids. Baker City, OR: Wallowa-Whitman National Forest.

USDA Forest Service. 2001. 1 Meter Digital Orthophotos. Baker City, OR: WallowaWhitman National Forest.

[USDA, nRCS] US Department of Agriculture, Natural Resources Conservation SERVICE. 2005. Soil Survey Geographic (SSURGO) database for Wallowa County Area, Oregon. Fort Worth, TX: USDA, NRCS. Available at: http:// SoilDataMart.nrcs.usda.gov/. Accessed 9 April 2007.

Vilà, M., J. A. Burriel, J. Pino, J. Chamizo, E. Llach, M. Porterias, and M. Vives. 2003. Association between Opuntia species invasion and changes in land-cover in the Mediterranean region. Global Change Biology 9:1234-1239.

Vitousek, P. M., C. M. D’Antonio, L. L. Loope, and R. Westbrooks. 1996. Biological invasions as global environmental change. American Scientist 84:468-478.

Wiles, L., AND M. BrodAHL. 2004. Exploratory data analysis to identify factors influencing spatial distributions of weed seed banks. Weed Science 52:936-947.

ZounaR, K. 2003. Potentilla recta. In: Fire Effects Information System US Department of Agriculture, Forest Service, Rocky Mountain Research Station, Fire Sciences Laboratory (producer). Available at: http://www.fs.fed.us/ database/feis/. Accessed 23 January 2007. 